\title{
Comparative Study of the Total Cellular Fatty Acids of Staphylococcus Species of Human Origin $\dagger$
}

\author{
DON R. DURHAM AND WESLEY E. KLOOS \\ Departments of Microbiology and Genetics, North Carolina State University, Raleigh, \\ North Carolina 27650
}

The cellular fatty acid compositions of 100 strains representing 10 different species of Staphylococcus were analyzed by gas-liquid chromatography. Results indicated that the fatty acid compositions of the various species were qualitatively similar with the exception of that of $S$. warneri, which contained a $\mathrm{C}_{22}$ fatty acid component. The species differed quantitatively with respect to relative percentages of fatty acid components. The major fatty acids were $\mathrm{C}_{15 \mathrm{Br}}, \mathrm{C}_{17 \mathrm{Br}}, \mathrm{C}_{16}, \mathrm{C}_{18}$, and $\mathrm{C}_{20}$. S. warneri and $S$. saprophyticus can be differentiated in most cases from all of the other species studied by the presence of significantly higher percentages of $\mathrm{C}_{20}$ and $\mathrm{C}_{16}$ fatty acids, respectively. Other species or groups of related species could also be separated on the basis of combinations of fatty acid components. These findings corroborate the newly proposed scheme of classification of the staphylococci, but the particular usefulness of gas-liquid chromatography of fatty acids for the identification of clinically significant, coagulase-negative staphylococci from humans is primarily limited to $S$. saprophyticus and possibly $S$. haemolyticus. However, application of the method may be useful in clarifying further the phenetic relationships of certain species and may have some ecological value.

The identification and differentiation of bacteria by gas-liquid chromatography (GLC) was proposed by Abel et al. (1). GLC analysis of metabolic products $(3,4,22,24)$ and structural components, particularly fatty acids $(2,5,17,23$, $25)$ and hydrocarbons $(21,29)$, has been recognized as a potential tool for delineating bacterial genera and species.

Recent studies on the natural populations of cutaneous bacteria from human and other animal sources have resulted in amended descriptions of S. epidermidis and S. saprophyticus and the characteriziation of eight new coagulase-negative species $(11,13,28)$. Although the cellular fatty acids and lipids of $S$. aureus and S. epidermidis have been investigated $(8,14-16,30$, 31 ), they have not yet been studied in S. saprophyticus and the newly proposed coagulase-negative species. (Whether strains used in the investigations cited here represent $S$. epidermidis sensu structo or other coagulase-negative species is unknown.) The present study was initiated to compare the cellular fatty acid compositions of all known human Staphylococcus species to provide additional information on their phenetic relationships and to provide the diagnostic laboratory possessing GLC capability with additional criteria for identification.

† Paper no. 5187 of the Journal Series of the North Carolina Agricultural Experiment Station, Raleigh, N.C.

\section{MATERIALS AND METHODS}

Bacterial strains. The strains used in this study are listed in Table 1.

Media and growth conditions. The organisms were grown in 125-ml Erlenmeyer flasks containing 50 $\mathrm{ml}$ of Trypticase soy broth with dextrose (BBL). Cultures were prepared by inoculating the above-mentioned medium with approximately $10^{8}$ colony-forming units from an 18-h-old agar slant culture and then incubating on a rotary shaker $(200 \mathrm{rpm})$ at $34^{\circ} \mathrm{C}$ for 24 h. Cells were harvested by centrifugation and washed twice with $67 \mathrm{mM}$ Sorenson phosphate buffer $(\mathrm{pH}$ 7.0).

Preparation of fatty acid methyl esters. Cellular fatty acids were converted to methyl esters directly from wet-cell preparations by transesterification as described by Dunlap and Perry (6). Washed-cell pellets were suspended in a solution of $3 \mathrm{ml}$ of $14 \%$ boron trifluoride-methanol and $3 \mathrm{ml}$ of benzene. Suspensions were transferred to Teflon-lined, screw-capped tubes and incubated overnight in a water bath at $60^{\circ} \mathrm{C}$. The benzene layer, separated from the emulsion by the addition of $4 \mathrm{ml}$ of distilled water and subsequent centrifugation, was removed and brought to dryness under nitrogen. The fatty acid methyl esters were suspended in hexane and analyzed by GLC.

GLC. The GLC analysis of the fatty acid methyl esters was done on a Varian gas chromatograph, series 2400, equipped with dual hydrogen-flame detectors. The chromatographic analysis was carried out in a copper column $(1.8 \mathrm{~m}$ by $0.3 \mathrm{~cm})$ containing $15 \%$ diethylene glycol succinate on 60/70-mesh Gas-Chrom Q. Operating conditions were as follows: column tem- 
TABLE 1. Bacterial strains of human origin used in this study

\begin{tabular}{|c|c|c|c|c|c|}
\hline Species & Strain no. & $\begin{array}{l}\text { Source or refer- } \\
\text { ence }\end{array}$ & Species & Strain no. & $\begin{array}{c}\text { Source or refer- } \\
\text { ence }\end{array}$ \\
\hline $\begin{array}{l}\text { Staphylococcus } \\
\text { simulans }\end{array}$ & $\begin{array}{l}\text { ATCC } 27848^{a} \\
\text { ATCC } 27849 \\
\text { ATCC } 27850 \\
\text { ATCC } 27851 \\
\text { CE 13 } \\
\text { MAW 222 } \\
\text { AW 232 } \\
\text { DW 196 } \\
\text { KL 299 } \\
\text { KH 12 }\end{array}$ & $\begin{array}{l}11 \\
11 \\
11 \\
11 \\
11 \\
11 \\
11 \\
11 \\
11 \\
11\end{array}$ & S. haemolyticus & $\begin{array}{l}\text { DSM 20263 } \\
\text { DSM } 20264 \\
\text { DSM 20265 } \\
\text { KES } 23 \\
\text { KL } 109 \\
\text { AS } 22 \\
\text { DM } 293 \\
\text { HM } 26 \\
\text { MK } 67 \\
\text { DM } 70\end{array}$ & $\begin{array}{l}28 \\
28 \\
28 \\
28 \\
28 \\
28 \\
28 \\
28 \\
28 \\
28\end{array}$ \\
\hline S. cohnii & $\begin{array}{l}\text { DSM } 20260^{a} \\
\text { DSM 20261 } \\
\text { DSM 20262 } \\
\text { JRM 24 } \\
\text { LK 478 } \\
\text { CK 27 } \\
\text { KH 201 } \\
\text { BB 3 } \\
\text { DM 272 } \\
\text { MK 247 }\end{array}$ & $\begin{array}{l}28 \\
28 \\
28 \\
28 \\
28 \\
28 \\
28 \\
28 \\
28 \\
28\end{array}$ & S. hominis & $\begin{array}{l}\text { ATCC } 27844^{a} \\
\text { ATCC } 27845 \\
\text { ATCC } 27846 \\
\text { ATCC } 27847 \\
\text { WK 227 } \\
\text { DGS 13 } \\
\text { SM 67 } \\
\text { JL 248 } \\
\text { AW 178 } \\
\text { TW 52 }\end{array}$ & $\begin{array}{l}11 \\
11 \\
11 \\
11 \\
11 \\
11 \\
11 \\
11 \\
11 \\
11\end{array}$ \\
\hline S. xylosus & $\begin{array}{l}\text { DSM 20266 } \\
\text { DMS 20267 } \\
\text { DM 37 } \\
\text { AW 124 } \\
\text { GH 30 } \\
\text { TW 41 } \\
\text { AW 244 } \\
\text { SE 4 } \\
\text { KH 168 } \\
\text { LK 236 }\end{array}$ & $\begin{array}{l}28 \\
28 \\
28 \\
28 \\
28 \\
28 \\
28 \\
28 \\
28 \\
28\end{array}$ & S. epidermidis & $\begin{array}{l}\text { JRM 1 } \\
\text { MCS 21 } \\
\text { MK 214 } \\
\text { AW } 269 \\
\text { DM 206 } \\
\text { KL 280 } \\
\text { PM 340 } \\
\text { RK 13 } \\
\text { RM 351 } \\
\text { WK 5 }\end{array}$ & $\begin{array}{l}28 \\
28 \\
28 \\
28 \\
28 \\
28 \\
28 \\
28 \\
28 \\
28\end{array}$ \\
\hline S. saprophyticus & $\begin{array}{l}\text { SE } 11 \\
\text { AW } 163 \\
\text { DM } 115 \\
\text { KL } 150 \\
\text { RM 454 } \\
\text { GH } 196 \\
\text { KL 20 } \\
\text { TW } 111 \\
\text { JRM } 27 \\
\text { SM } 115\end{array}$ & $\begin{array}{l}28 \\
28 \\
28 \\
28 \\
28 \\
28 \\
28 \\
28 \\
28 \\
28\end{array}$ & S. capitis & $\begin{array}{l}\text { ATCC } 27840^{\alpha} \\
\text { ATCC } 27841 \\
\text { ATCC } 27842 \\
\text { ATCC } 27843 \\
\text { GS } 14 \\
\text { KH } 220 \\
\text { RK } 23 \\
\text { PM } 378 \\
\text { CK } 17 \\
\text { KES } 14\end{array}$ & $\begin{array}{l}11 \\
11 \\
11 \\
11 \\
11 \\
11 \\
11 \\
11 \\
11 \\
11\end{array}$ \\
\hline S. warneri & $\begin{array}{l}\text { ATCC } 27836^{a} \\
\text { ATCC } 27837 \\
\text { ATCC } 27838 \\
\text { ATCC 27839 } \\
\text { SM 251 } \\
\text { KH 208 } \\
\text { SM 244 } \\
\text { JL 286 } \\
\text { KL 105 } \\
\text { TW 98 }\end{array}$ & $\begin{array}{l}11 \\
11 \\
11 \\
11 \\
11 \\
11 \\
11 \\
11 \\
11 \\
11\end{array}$ & S. aureus & $\begin{array}{l}\text { DBM 34 } \\
\text { DM } 171 \\
\text { PM } 26 \\
335 \\
\text { R } 126 \\
\text { S } 36 \\
\text { CDC 41734-74 } \\
75: 556^{b} \\
75: 560^{b} \\
\text { SAH }\end{array}$ & $\begin{array}{l}\text { W. E. Kloos } \\
\text { W. E. Kloos } \\
\text { W. E. Kloos } \\
\text { W. H. Sperbee } \\
\text { W. H. Sperbe } \\
\text { W. H. Sperbe } \\
\text { G. A. Hancocl } \\
\text { G. A. Hancoch } \\
\text { G. A. Hancock } \\
\text { R. M. Cody }\end{array}$ \\
\hline
\end{tabular}

a Type strain.

${ }^{b}$ Clinical isolates from the Center for Disease Control, Atlanta, Ga.

perature, $170^{\circ} \mathrm{C}$; injector and detector temperature, $190^{\circ} \mathrm{C}$; and argon flow rate, $20 \mathrm{ml} / \mathrm{min}$.

Fatty acid methyl esters were tentatively identified by comparisons of retention time to standard fatty acid methyl esters (Applied Science Laboratories). Confirmation of unsaturated fatty acids was accomplished by hydrogenation of methyl esters with hydrogen-platinum oxide and examination for possible peak 
shifts (8). Quantitation of fatty acids was determined as previously described (6).

Mass spectrometry. Confirmation of fatty acid components was accomplished by analyzing fatty acid methyl esters of selected species with a Hewlett Packard HP5982A GLC-mass spectrometer and a HP5934A data system. The chromatographic analysis was carried out in a 500 -foot by 0.02 -inch (inner diameter; about $151 \mathrm{~m}$ by $0.05 \mathrm{~cm}$ ) stainless-steel column coated with OV-17. The GLC oven temperature was programmed from 150 to $290^{\circ} \mathrm{C}$, and the source temperature was $200^{\circ} \mathrm{C}$. The ionizing voltage of the mass spectrometer was $70 \mathrm{eV}$. GLC mass spectrometry of fatty acid methyl esters was performed by J. D. Weete (Auburn University, Auburn, Ala.).

\section{RESULTS AND DISCUSSION}

The percentages of the total cellular fatty acids for Staphylococcus species isolated from human skin are presented in Table 2. The fatty acid compositions of the staphylococci were qualitatively similar, with the exception of that of $S$. warneri, which contained $\mathrm{C}_{22}$ fatty acid. All species had fatty acids which were in the range of $\mathrm{C}_{12}$ to $\mathrm{C}_{21}$ and which consisted of iso and anteiso methyl-branched structures and occasional normal structures for odd-numbered carbon chains and iso and normal structures for even-numbered chains. We were unable to completely resolve $\mathrm{C}_{15 \mathrm{Br}}, \mathrm{C}_{17 \mathrm{Br}}, \mathrm{C}_{19 \mathrm{Br}}$, and $\mathrm{C}_{21 \mathrm{Br}}$ into iso and anteiso components for the conditions described. However, mass spectra analysis of selected strains confirmed that iso and anteiso forms were present for these chain lengths. The predominent isomers of $\mathrm{C}_{15 \mathrm{Br}}$ and $\mathrm{C}_{17 \mathrm{Br}}$ were the anteiso derivatives. Similar results have been reported for $S$. aureus (31) and $S$. epidermidis (14). The major fatty acids were $\mathrm{C}_{15 \mathrm{Br}}, \mathrm{C}_{17 \mathrm{Br}}$, $\mathrm{C}_{19 \mathrm{Br}}, \mathrm{C}_{16}, \mathrm{C}_{18}$, and $\mathrm{C}_{20}$. No unsaturated fatty acids were detected.

The results indicated that $S$. warneri and $S$. saprophyticus could be separated in most cases from all other species by their higher percentages of $\mathrm{C}_{20}$ and $\mathrm{C}_{16}$ fatty acids, respectively (Fig. 1). Only one strain of $S$. capitis (namely GS14) contained $47.3 \% \mathrm{C}_{20}$, a value which overlapped with that obtained with $S$. warneri, and one strain of $S$. warneri (namely KL105) contained $43.9 \% \mathrm{C}_{20}$, a value which overlapped with that obtained with $S$. capitis. Two unusual strains of S. saprophyticus (namely JRM27 and GH196) contained 6.9 and $8.7 \% \mathrm{C}_{16}$, respectively, values that were low enough to overlap with those of $S$. xylosus and S. simulans. Other species or groups of related species could also be separated on the basis of combinations of fatty acid constituents.

$S$. aureus strains isolated from healthy human skin and clinical infections represented a fairly homogeneous group. The fatty acid compositions obtained in this study were similar to those previously reported, with $\mathrm{C}_{15 \mathrm{Br}}$ as the major fatty acid $(8,29,31)$. Considerable amounts of $\mathrm{C}_{17 \mathrm{Br}}$, $\mathrm{C}_{18}$, and $\mathrm{C}_{20}$ fatty acids were also detected. It is particularly interesting that $S$. aureus and $S$. haemolyticus are similar in fatty acid composition, with the exception of the $\mathrm{C}_{19 \mathrm{Br}}$ fraction.

$S$. simulans, a relatively uncommon species which shares several phenotypic characteristics with $S$. aureus, also contained a $\mathrm{C}_{15 \mathrm{Br}}$ fraction as its predominant fatty acid and a relatively large percentage of $\mathrm{C}_{18}$ and $\mathrm{C}_{20}$ fatty acids. This species differs from $S$. aureus in that it contains a significantly higher percentage of $\mathrm{C}_{16}$ and usually a lower percentage of $\mathrm{C}_{17 \mathrm{Br}}$ fatty acid (Fig. 1).

S. warneri, S. hominis, and S. haemolyticus comprise a group of related coagulase-negative species that may occasionally be confused with one another on the basis of simple character analysis (12). Most errors, when they occur, are between $S$. warneri and the other species. Relative rates of migration of esterase enzymes using gel electrophoresis (33) are quite useful in differentiating $S$. hominis from $S$. warneri and $S$. haemolyticus but have limited use in separating $S$. warneri from $S$. haemolyticus. In the present study, we have shown that fatty acid composition clearly distinguishes $S$. warneri from $S$. hominis and S. haemolyticus. The normal $\mathrm{C}_{20}$ fraction and $\mathrm{C}_{15 \mathrm{Br}}, \mathrm{C}_{17 \mathrm{Br}}$, and $\mathrm{C}_{19 \mathrm{Br}}$ fractions can be used to separate $S$. warneri from these species (Fig. 1). In addition, a $\mathrm{C}_{22}$ fraction was detected only in S. warneri. S. haemolyticus and $S$. hominis yielded rather similar fatty acid patterns but possessed minor differences in the $\mathrm{C}_{18}$ and $\mathrm{C}_{20}$ fractions.

$S$. capitis can be readily distinguished from $S$. hominis and $S$. haemolyticus by their levels of $\mathrm{C}_{15 \mathrm{Br}}, \mathrm{C}_{17 \mathrm{Br}}, \mathrm{C}_{19 \mathrm{Br}}$, and $\mathrm{C}_{20}$ fatty acids. Moreover, the unique percentages of $\mathrm{C}_{15 \mathrm{Br}}$ and $\mathrm{C}_{18}$ fractions, taken together, can be utilized to separate $S$. capitis from all other species. The fatty acid composition of this species parallels that of $S$. warneri with the exception of the $\mathrm{C}_{18}$ and $\mathrm{C}_{20}$ fractions (Fig. 1).

S. epidermidis possessed fatty acid patterns qualitatively similar to those previously reported $(8,14)$. However, lower levels of $\mathrm{C}_{15 \mathrm{Br}}$ and higher levels of $\mathrm{C}_{20}$ fatty acids were observed in this study. S. epidermidis strains contained $\mathrm{C}_{20}$ $(33.0 \%), \mathrm{C}_{15 \mathrm{Br}}(27.6 \%)$, and $\mathrm{C}_{18}(15.4 \%)$ as the principal fatty acids. It is interesting to note that the fatty acid compositions of $S$. epidermidis and $S$. hominis are nearly identical. These organisms are the most prevalent and persistent Staphylococcus species isolated from humans, and they produce large populations in warm, moist habitats of the skin (10).

$S$. saprophyticus, $S$. xylosus, and $S$. cohnii comprise a group of related species that are distinguished from other staphylococci by their 
TABLE 2. Mean percentages and standard deviations of cellular fatty acid components of Staphylococcus species

\begin{tabular}{|c|c|c|c|c|c|c|c|c|c|c|c|c|c|c|}
\hline $\begin{array}{c}\begin{array}{c}\text { Staphylococcus } \\
\text { species }\end{array} \\
\end{array}$ & $\mathrm{C}_{12}$ & $C_{14 \text { isso }}$ & $\mathrm{C}_{14}$ & $\mathrm{C}_{15} \mathrm{Br}^{a}$ & $\mathrm{C}_{16 \mathrm{i} \text { iso }}$ & $\mathrm{C}_{16}$ & $\mathrm{C}_{17 \mathrm{Br}}{ }^{a}$ & $\mathrm{C}_{18 \mathrm{isio}}$ & $\mathrm{C}_{18}$ & $\mathrm{C}_{19 \mathrm{Br}^{a}}{ }^{a}$ & $\mathrm{C}_{19}$ & $\mathrm{C}_{20}$ & $\mathrm{C}_{21 \mathrm{Br}}$ & $\mathrm{C}_{22}$ \\
\hline S. aureus & $0.7 \pm 0.2^{b}$ & $1.8 \pm 0.7$ & $0.2 \pm 0.05$ & $34.8 \pm 3.7$ & $1.5 \pm 0.06$ & $3.1 \pm 0.5$ & $10.2 \pm 3.1$ & $0.6 \pm 0.3$ & $19.5 \pm 2.5$ & $\begin{array}{c}1.9 \pm 0.8 \\
(2.5 \pm 0.9)\end{array}$ & $0.9 \pm 0.2$ & $21.7 \pm 4.6$ & $0.6 \pm 0.1$ & $\mathrm{ND}^{r}$ \\
\hline S. simulans & $1.2 \pm 0.4$ & $2.3 \pm 0.6$ & $1.0 \pm 0.4$ & $37.2 \pm 6.9$ & $0.6 \pm 0.2$ & $7.9 \pm 1.3$ & $4.8 \pm 2.8$ & $0.3 \pm 0.1$ & $23.1 \pm 3.5$ & $1.1 \pm 0.4$ & $0.3 \pm 0.2$ & $20.2 \pm 5.1$ & ND & ND \\
\hline S. epiderm & $0.8 \pm$ & $7 \pm 0.2$ & $0.3 \pm$ & $27.6 \pm 4.2$ & $0.3 \pm 0.2$ & $2.0 \pm 1.1$ & $6.8 \pm 2.5$ & $0.3 \pm 0.2$ & $15.4 \pm 2.7$ & $\begin{array}{c}7.2 \pm 2.9 \\
(5.1 \pm 3.7)\end{array}$ & $0.1 \pm 0.2$ & $33.0 \pm 7.6$ & $0.4 \pm 0.5$ & ND \\
\hline S. capitis : & $2.9 \pm 1.1$ & $0.8 \pm 0.3$ & $1.5 \pm 0.9$ & $20.0 \pm 4.2$ & $0.3 \pm 0.1$ & $4.7 \pm 2.4$ & $2.7 \pm 1.5$ & $0.4 \pm 0.3$ & $23.2 \pm 4.0$ & $2.4 \pm 1.5$ & $0.5 \pm 0.2$ & $39.9 \pm 7.1$ & $0.5 \pm 0.6$ & ND \\
\hline S. warneri & $0.6 \pm 0.2$ & $1 \pm 0.4$ & $4.1 \pm 1.6$ & $18.7 \pm 4.8$ & $0.2 \pm 0.1$ & $5.1 \pm 1.9$ & $1.5 \pm 0.4$ & $0.2 \pm 0.9$ & $14.7 \pm 2.2$ & $\begin{array}{c}0.9 \pm 0.3 \\
(0.8 \pm 0.3)\end{array}$ & ND & $48.3 \pm 2.1$ & $0.5 \pm 0.3$ & $3.2 \pm 1.6$ \\
\hline S. haemolyticus & $0.3 \pm 0.3$ & $0.9 \pm 0.4$ & $0.2 \pm 0.09$ & $33.6 \pm 2.5$ & $0.8 \pm 0.3$ & $2.8 \pm 0.9$ & $10.7 \pm 2.3$ & $0.4 \pm 0.2$ & $23.0 \pm 3.7$ & $\begin{array}{c}4.7 \pm 1.6 \\
(4.0 \pm 1.8)\end{array}$ & $0.7 \pm 0.4$ & $17.6 \pm 1.5$ & $0.3 \pm 0.2$ & ND \\
\hline S. hominis & $0.8 \pm 0.8$ & $0.5 \pm 0.2$ & $0.2 \pm 0.2$ & $32.4 \pm 3.2$ & $0.2 \pm 0.08$ & $1.5 \pm 0.8$ & $7.3 \pm 3.1$ & $0.3 \pm 0.1$ & $16.6 \pm 3.6$ & $\mid \begin{array}{c}7.2 \pm 2.8 \\
(8.1 \pm 3.0)\end{array}$ & ND & $24.2 \pm 5.8$ & $0.7 \pm 0.8$ & ND \\
\hline S. saprophyticus & $1.7 \pm 0.6$ & $2.0 \pm 1.0$ & $6.8 \pm 5.0$ & $27.5 \pm 7.6$ & $0.4 \pm 0.3$ & $12.1 \pm 2.8$ & $4.0 \pm 2.7$ & $0.3 \pm 0.3$ & $15.6 \pm 4.0$ & $2.2 \pm 1.2$ & $0.4 \pm 0.2$ & $26.8 \pm 5.1$ & $0.2 \pm 0.3$ & ND \\
\hline S. $c$ & $0.5 \pm 0.4$ & $1.2 \pm 0.9$ & $1.3 \pm 0.8$ & $42.5 \pm 6.0$ & $1.2=$ & $5.6 \pm 1.5$ & $11.4 \pm 3.5$ & $0.5 \pm 0.2$ & $14.5 \pm 3.2$ & $3.3 \pm 0.9$ & $0.3 \pm 0.2$ & $17.4 \pm 3.0$ & $0.3 \pm 0.2$ & ND \\
\hline S. xylosus & $2.3 \pm 0.7$ & $2.2 \pm 0.7$ & $3.2 \pm 1.5$ & $36.4 \pm 5.9$ & $0.8 \pm 0.4$ & $8.0 \pm 1.4$ & $8.8 \pm 2.6$ & $0.4 \pm 0.2$ & $17.3 \pm 2.7$ & $3.3 \pm 1.0$ & $0.4 \pm 0.1$ & $16.9 \pm 3.5$ & $0.07 \pm 0.2$ & ND \\
\hline
\end{tabular}

${ }^{a} \mathrm{C}_{15 \mathrm{Br}}, \mathrm{C}_{17 \mathrm{Br}}$, and $\mathrm{C}_{19 \mathrm{Br}}$ contained iso and anteiso components confirmed by mass spectra analysis of $S$. warneri MK 155, S. haemolyticus AS 22 , and $S$. hominis WK 227. $\mathrm{C}_{19 \mathrm{Br}}$ anteiso components, in parentheses, were resolved for $S$. aureus, S. epidermidis, S. warneri, S. haemolyticus, and $S$. hominis. Br, Branched.

${ }^{b}$ Data represent the mean percentages and standard deviations of 10 strains for each species. Duplicate independent determinations for each strain varied from 1 to $25 \%$.

${ }^{c}$ ND, Not detected. 

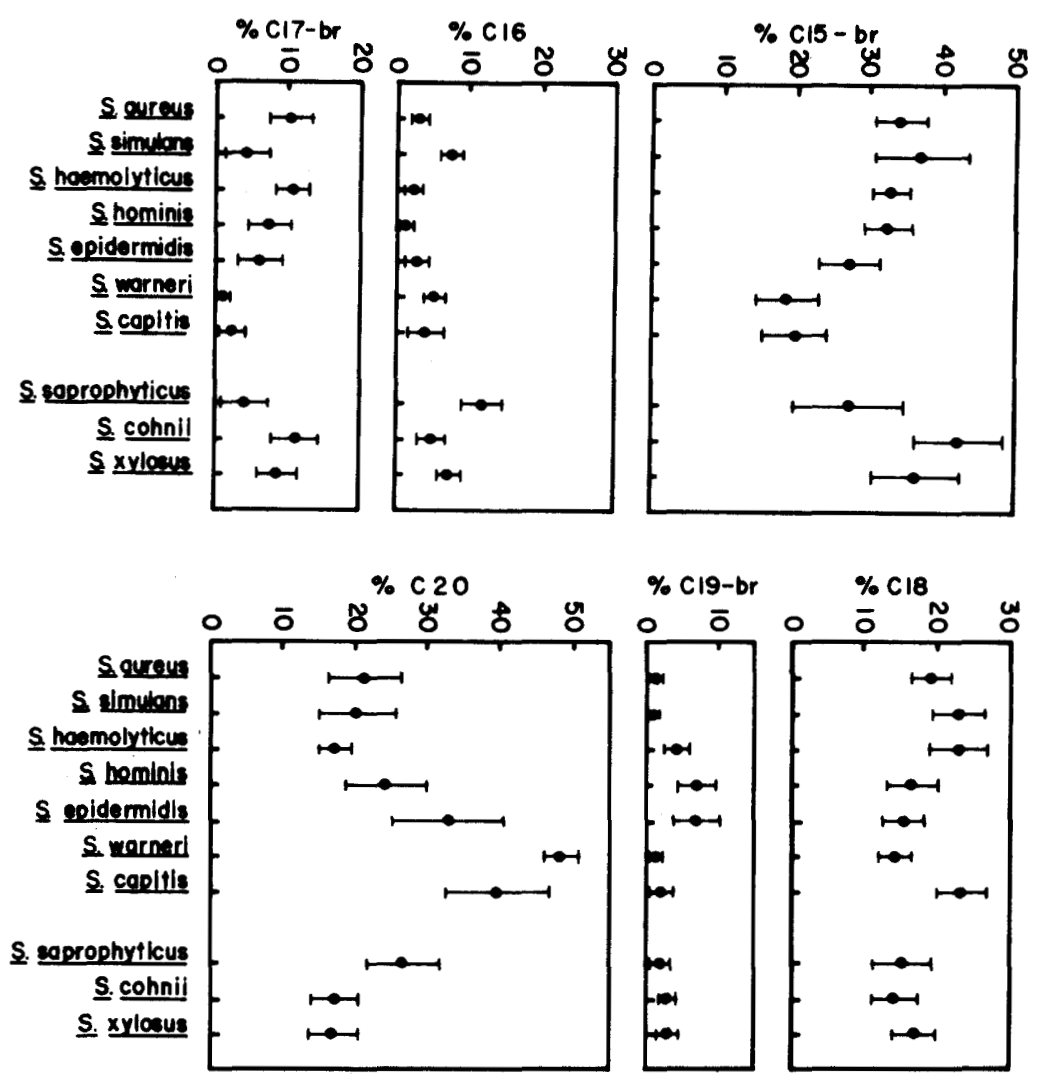

Fig. 1. Comparison of the relative percentages of the major fatty acid components of Staphylococcus species. Points and bars represent the means and the standard deviations of 10 strains for each species.

resistance to novobiocin, cell wall composition, low acid production from glucose under anaerobic conditions, high salt tolerance, and their lack of, or limited, organic nitrogen requirements (7, $11,28)$. S. saprophyticus contained almost equivalent quantities of $\mathrm{C}_{15 \mathrm{Br}}$ and $\mathrm{C}_{20}$ fatty acids. It was found to be different from S. xylosus and $S$. cohnii in the percentage of $C_{20}$ fatty acid. $S$. xylosus and $S$. cohnii are indistinguishable in their fatty acid patterns.

In light of the recent evidence that several coagulase-negative species, particularly $S$. epidermidis, S. saprophyticus, S. haemolyticus, and $S$. hominis, have been associated with human infections $(18,20,26,27)$, it was initially hoped that GLC analysis of the cellular fatty acids could be utilized for the clinical identification of these species. Results suggest that cellular fatty acid composition alone would not completely separate $S$. hominis and $S$. epidermidis from each other, although it would clearly separate $S$. saprophyticus from these and most other species. $S$. haemolyticus, in most instances, can be separated from $S$. hominis and $S$. epidermidis based on the percentage of $\mathrm{C}_{20}$ fatty acid. In ecological studies, cellular fatty acid composition may be useful in separating $S$. warneri from other staphylococci. Recent studies have suggested that this species is only occasionally found on healthy human skin or in infections $(10,26)$, although its presumed subspecies are commonly found on the skins of primates other than man (W. E. Kloos, unpublished data). The occurrence of $S$. warneri in nonhuman primate infections has not yet been determined.

\section{ACKNOWLEDGMENTS}

We thank J. D. Weete for kindly performing GLC mass spectrometry and Robbin Evans (University of New Orleans, New Orleans, La.) for her technical assistance.

This study was supported by Public Health Service grant BRSG No. RR 7071 from the National Institutes of Health.

\section{REPRINT REQUESTS}

Address reprint requests to: Dr. Don R. Durham, Dept. of Microbiology and Genetics, North Carolina State University, Raleigh, NC 27607.

\section{LTERATURE CITED}

1. Abel, K., H. DeSchmertzing, and J. Peterson. 1963. Classification of microorganisms by analysis of chemical composition. I. Feasibility of utilizing gas chromatog- 
raphy. J. Bacteriol. 85: 1039-1044.

2. Amstein, C. F., and P. A. Hartman. 1973. Differentiation of some enterococci by gas chromatography. J. Bacteriol. 113:38-41.

3. Brooks, J. B., M. J. Selin, and C. C. Alley. 1976. Electron capture gas chromatography of the acids and alcohol products of Clostridium septicum and Clostridium chauvoei. J. Clin. Microbiol. 3:180-185.

4. Brooks, J. B., R. E. Weaver, H. W. Tatum, and S. A. Billingsley. 1972. Differentiation between Pseudomonas testosteroni and $P$. acidovorans by gas chromatography. Can. J. Microbiol. 18:1477-1482.

5. Druker, D. B. 1974. Chemotaxonomic fatty acid fingerprints of some streptococci with subsequent statistical analysis. Can. J. Microbiol. 20:1723-1727.

6. Dunlap, K. R., and J. J. Perry. 1967. Effect of substrate on the fatty acid composition of hydrocarbon-utilizing microorganisms. J. Bacteriol. 94:1919-1923.

7. Emmett, M., and W. E. Kloos. 1975. Amino acid requirements of staphylococci isolated from human skin. Can. J. Microbiol. 21:729-733.

8. Ishizuka, I., N. Ueta, and T. Yamakama. 1966. Gas chromatographic studies of microbial components. II. Carbohydrate and fatty acid constitution of the family Micrococcaceae. Jpn. J. Exp. Med. 36:73-83.

9. King, D. H., and J. J. Perry. 1975. The origin of fatty acids in the hydrocarbon-utilizing microorganism $\boldsymbol{M y}$. cobacterium vaccae. Can. J. Microbiol. 21:85-89.

10. Kloos, W. E., and M. S. Musselwhite. 1975. Distribution and persistence of Staphylococcus and Micrococcus species and other aerobic bacteria on human skin. Appl. Microbiol. 30:381-395.

11. Kloos, W. E., and K. H. Schleifer. 1975. Isolation and characterization of staphylococci from human skin. II. Descriptions of four new species: Staphylococcus warneri, Staphylococcus capitis, Staphylococcus hominis, and Staphylococcus simulans. Int. J. Syst. Bacteriol. 25:62-79.

12. Kloos, W. E., K. H. Schleifer, and W. C. Noble. 1976. Estimation of character parameters in coagulase-negative Staphylococcus species, p. 23-41. In J. Jeljaszewicz (ed.), Staphylococci and staphylococcal diseases. Gustav Fischer Verlag, Stuttgart.

13. Kloos, W. E., K. H. Schleifer, and R. F. Smith. 1976 Characterization of Staphylococcus sciuri sp. nov, and its subspecies. Int. J. Syst. Bacteriol. 26:22-37.

14. Komaratat, P., and M. Kates. 1975. The lipid composition of a halotolerant species of Staphylococcus epidermidis. Biochim. Biophys. Acta 398:464-484.

15. Kushwaha, S. C., and M. Kates. 1976. Non-polar lipids of a halotolerant species of Staphylococcus epidermidis. Can. J. Biochem. 54:79-85.

16. MacFarlane, M. G. 1962 . Lipid components of Staphy. lococcus aureus and Salmonella typhimurium. Biochem. J. 82:40P-41P.

17. Machtiger, N. A., and W. M. O'Leary. 1973. Fatty acid compositions of paracolons: Arizona, Citrobacter, and Providencia. J. Bacteriol. 114:80-85.

18. Maskell, R. 1974. Importance of coagulase-negative staphylococci as pathogens in the urinary tract. Lancet i: $1155-1158$.

19. Meyer, D. M., and D. J. Blazevic. 1970. Differentiation of human mycoplasma using gas chromatography. Can. J. Microbiol. 17:297-300.

20. Mitchell, R. G. 1964. Urinary tract infections due to coagulase-negative staphylococci. J. Clin. Pathol. 17:105-106.

21. Morrison, S. J., T. G. Tornabene, and W. E. Kloos. 1971. Neutral lipids in the study of relationships of the members of the family Micrococcaceae. J. Bacteriol. 108:353-358

22. Moss, C. W., and C. M. Kaltenbach. 1974. Production of glutaric acid: a useful criterion for differentiating Pseudomonas diminuta from Pseudomonas vesiculare. Appl. Microbiol. 27:437-439.

23. Moss, C. W., and V. J. Lewis. 1967. Characterization of clostridia by gas chromatography. I. Differentiation of species by cellular fatty acids. Appl. Microbiol. 15:390-397.

24. Moss, C. W., and S. B. Samuels. 1974. Short-chain acids of Pseudomonas species encountered in clinical specimens. Appl. Microbiol. 27:570-574.

25. Moss, C. W., S. B. Samuels, and R. E. Weaver. 1974. Cellular fatty acid composition of selected Pseudo. monas species. Appl. Microbiol. 24:596-598.

26. Nord, C., S. Holta-Oie, A. Ljungh, and T. Wadstrom. 1976. Characterization of coagulase-negative staphylococcal species from human infections, p. 105-111. In J. Jeljaszewicz (ed.), Staphylococci and staphylococcal diseases. Gustav Fischer Verlag, Stuttgart.

27. Oeding, P., and A. Digranes. 1976. Staphylococcus sap. rophyticus: classifications and infections, p. 113-117. In J. Jeljaszewicz (ed.), Staphylococci and staphylococcal diseases. Gustav Fischer Verlag, Stuttgart.

28. Schleifer, K. H., and W. E. Kloos. 1975. Isolation and characterization of staphylococci from human skin. I. Amended descriptions of Staphylococcus epidermidis and Staphylococcus saprophyticus and descriptions of three new species: Staphylococcus cohnii, Staphylococcus haemolyticus, and Staphylococcus xylosus. Int. J. Syst. Bacteriol, 25:50-61.

29. Tornabene, T. G., S. J. Morrison, and W. E. Kloos. 1970. Aliphatic hydrocarbon content of various members of the family Micrococcaceae. Lipids 5:929-937.

30. White, D. C., and F. E. Frerman. 1967. Extraction, characterization, and cellular localization of lipids of Staphylococcus aureus. J. Bacteriol. 94:1854-1867.

31. White, D. C., and F. E. Frerman. 1968. Fatty acid composition of the complex lipids of Staphylococcus aureus during the formation of membrane-bound electron transport system. J. Bacteriol. 95:2198-2209.

32. Zimmerman, R. J. 1976. Comparative electrophoresis of catalases of Staphylococcus species isolated from mammalian skin. Can. J. Microbiol. 22:1691-1698.

33. Zimmerman, R. J., and W. E. Kloos. 1976. Comparative electrophoresis of esterases of Staphylococcus species isolated from mammalian skin. Can. J. Microbiol. 22:771-779. 